\title{
Research on the Teaching Methods of College English
}

\author{
Xiaona Dong \\ College of Applied Technology, Southwest Petroleum University, Nanchong, China \\ Email: xiaona2088@163.com
}

Received 11 May 2016; accepted 17 June 2016; published 21 June 2016

Copyright (C) 2016 by author and Scientific Research Publishing Inc.

This work is licensed under the Creative Commons Attribution International License (CC BY). http://creativecommons.org/licenses/by/4.0/

(c) (i) Open Access

\begin{abstract}
With the development of our economy, the improvement of the market economy system, the talent competition and the rapid development of global economic integration, the society puts forward higher requirements for university students' quality. All walks of life are urgent to need a large number of advanced technical talents with a certain level of English. English has become an important tool to participate in international communication and competition. Therefore, it is required to improve the ability of Public English Teaching in order to meet the needs of the development of market economy. Therefore, the use of effective teaching methods and the improvement of the students' English learning effect are very important. However, how to effectively implement public English Teaching in college and how to improve college students' English proficiency through teaching have become an urgent problem to be solved. This research analyzes the problems existing in College English teaching, and puts forward a variety of methods to promote college English teaching effect, which can be used as a reference for college English teaching.
\end{abstract}

\section{Keywords}

College English, Teaching Methods, College Student, Teaching Effect

\section{Introduction}

With the pace of the globalization and internationalization of the world economy accelerating, the demand for English talents in all walks of life has become more and more strong (AAMC, 2005). For example, with the improvement of people's living standards, tourism has become a way of daily consumption. And the country also attaches great importance to the development of tourism. For the students of tourism major in colleges and universities, after graduation, they may enter the international hotel, tourist attractions or foreign tourism sector. In order to communication with foreign guests and complete their own work, the English level is very important. English teaching in colleges and universities in China, however, is only the pure theoretical teaching, and can't 
provide students with an English speaking environment which leads to college graduates cannot master the basic skills of using English for communication (Abou-Raya, A., \& Abou-Raya, S., 2010). Traditional English teaching mainly focuses on reading, while international cooperation focuses on cultivating students' ability to communicate. The purpose of this study is to understand the current situation of English teaching methods in colleges and universities, and to explore the problems existing in English Teaching in colleges and universities (Akesson, Dreinhofer, \& Woolf, 2003). And on this basis, a new method of teaching English is put forward to help college English teachers to improve the existing English teaching methods, improve the quality of college English teaching, enable students to master the solid English skills, and lay a solid foundation for employment.

\section{Problems in Current College English Teaching}

\subsection{Single Teaching Method, Obsolete Teaching Facilities}

At present, college English teaching is a single and old teaching mode. In the class, the teacher explains the English knowledge and grammar structure of the text or exam skills, while the students are sitting there passively accepting the knowledge. This teaching method can not attract students in the information age (Al-Nammari, James, \& Ramachandran, 2009). In recent years, colleges and universities continue to expand enrollment, the number of students suddenly increase, the class capacity continues to expand, however, teaching equipments are old. Due to the large number of students, but also the lack of effective auxiliary facilities, it is difficult for teacher to carry out the activities of the class and to mobilize the enthusiasm and initiative of students.

\subsection{The Lack of Correlation among Teaching, Learning and Using}

At present, the exam-oriented education occupy the main position, and the lack of practical education. In our colleges and universities, CET-4 and CET-6have been held for many years, each time there are millions of students to participate in the exam. This not only has a positive significance to improve the teaching level of English teachers, but also can promote students to learn English well. But in many colleges and universities, if students failed to pass the CET exams, will not be able to get a degree, lead to many teachers focus on cultivating the students' ability to exam (Almoallim, Bukhari, Amasaib, \& Zaini, 2012). What's more, some companies only attach importance to the candidate's test scores, ignoring the candidates other aspects of the talent. Students focus on examination skills, ignore the practical ability of English training, leading to many students lack of independent personality and practical spirit. Under the pressure of school and society, college English teaching has deviated from the true purpose of English teaching, and has become a test-oriented education. It is lack of correlation among teaching, learning and using, not only waste the time and energy, but also can not well complete the teaching goal.

\subsection{The Lack of Correlation among University Teaching, Secondary School Teaching and Primary School Teaching}

There is a lack of connection between secondary school textbooks and college teaching materials, which is a barrier to English learners. In the teaching material of university, middle-school and primary school in our country, there are many unnecessary repetitive content (Tian, Jiu, Xu, \& Wang, 2011). And there are different emphases in different stages of teaching. In primary and secondary schools, English learning is mainly based on a few textbooks, which mainly focuses on the teaching of grammar. Therefore, the students' vocabulary is relatively poor, and the ability of language application is poor. College English is focused on to grasp the usage of vocabulary and a variety of expression, not to teach grammar systematically. This is detrimental to the cultivation of students' practical ability, and can lead to negative consequences.

\section{Research on the Methods of Improving the Teaching Effect of College English Teaching}

\subsection{Layered Teaching Method}

Layered teaching method is aimed at different English level and different learning ability of students with different English teaching methods. Layered teaching, as one of the effective measures for quality-teaching, is teaching students in accordance with their aptitude (Wang, 2010). The issue satisfies the individual's difference 
sufficiently and develops the character of each student. Practice has proved that the method not only can effectively improve the academic performance of students, and significantly reduced the rate of poor students, effectively improve the colleges and universities present English teaching level. Before the implementation of layered teaching, we must meet the requirements of two aspects: first, has a comprehensive grasp to the students' English level; second, in the aspect of English teaching materials selection, to combine the students' English level. Therefore, in the process of implementing English teaching, the college can refer to the layered teaching method.

\subsection{Life-Related Teaching Method}

Life-related teaching method refers to integrate English teaching into life, learn English in life, master the basic skills of English in practice. Life-related teaching is an English teaching which is based on life. It is different from the traditional teaching methods in the selection of teaching materials, teaching process and teaching effect. life-related teaching is to let students learn English out of class, and to learn English in practice. Life-related teaching method breaks the traditional English teaching mode, and the students are liberated from the shackles of the traditional English teaching, which makes the students actively integrate into the teaching. Life-related teaching puts forward higher requirements to English teachers' teaching level and teaching theory (Xu, 2010). In the teaching level, it requires teachers to have a deep understanding of the teaching content, select the appropriate teaching material from life, and introduce the life material into the practical English teaching. In the aspect of teaching theory, the traditional English teaching pays attention to the training of students' vocabulary, grammar and sentence pattern, and the English teachers only need to master the theoretical knowledge of vocabulary, grammar, sentence patterns and so on. The life-related teaching attaches great importance to cultivate the students' comprehensive ability in our daily life, which requires the English teachers to master rich English teaching theory. Therefore, in the process of implementing English teaching, the college can refer to the life-related teaching method.

\subsection{Task-Based Teaching Method}

Task-based teaching method is to cultivate students' confidence in learning English through the gradual accumulation of the task. Task-based English teaching method is based on the task of the basic module, in the process of English teaching, to complete a series of tasks. In this process, English teachers and students can get along very well, and English teachers and students will be able to speak English in a real environment, to improve students' ability of English communication. Task-based teaching method compares with the traditional English teaching has the following advantages: first, task-based English teaching method has a very clear teaching goal; Second, the task-based teaching method is a kind of student-centered English teaching methods; Third, task-based teaching method is carried out around the students, each student has a certain task, prompting students to actively participate in the teaching of English. Task-based English teaching method not only put forward higher requirements to the English teachers in colleges and universities, but also put forward higher requirements to the students. In the aspect of English teachers, task-based teaching method requires English teachers to have a high comprehensive quality and strong professional knowledge, in the process of task allocation, to pay attention to the difficulty of the task. In the aspect of students, the task-based English teaching method requires that each student has a certain task, and everyone can't be lazy. Therefore, in the process of implementing English teaching, the college can refer to the task-based teaching method.

\subsection{Group-Divided and Cooperative Teaching Method}

Group-divided and cooperative teaching method is according to the interests and the English levels, divide students into groups. Each group as a small team, English teachers' teaching according to the actual situation of each team, at the same time, the requirement between team members, learn from each other, communicate with each other. According to the English teachers' teaching method, choose the appropriate method of learning English. On the one hand, group-divided and cooperative learning can enhance students' sense of team cooperation. On the other hand, it can improve students' ability to communicate in English quickly. Group-divided and cooperative teaching method is based on students' autonomous learning. In the process of English teaching, through the communication between the team members, stimulate students' interest in learning English, mobil- 
ize the enthusiasm and initiative of the students to learn English. In the process of group-divided and cooperative teaching, not only can strengthen students' team cooperation consciousness and responsibility, but also can achieve a comprehensive and sustainable development of students' learning English. Therefore, in the process of implementing English teaching, the college can refer to the group-divided and cooperative teaching method.

\section{Conclusion}

With the pace of the globalization and internationalization of the world economy accelerating, English, as a communication tool, is becoming more and more important. The goal of English Teaching in colleges and universities is to cultivate students' English practical ability and intercultural communicative competence through the use of effective English teaching methods. In order to improve the present situation of the current college English teaching methods, promote the reform of English teaching methods, improve teaching quality, colleges and universities should attach importance to reform of college English teaching, and actively promote the implementation of university teaching methods, to provide a good external environment for the reform of College English teaching.

\section{References}

AAMC (2005). Report VII Contemporary Issues in Medicine: Musculoskeletal Medicine Education, Medical School Objectives Project No. VII. Washington DC: Association of American Medical Colleges.

Abou-Raya, A., \& Abou-Raya, S. (2010). The Inadequacies of Musculoskeletal Education. Clinical Rheumatology, 29, 1121-1126. http://dx.doi.org/10.1007/s10067-010-1527-y

Akesson, K., Dreinhofer, K. E., \& Woolf, A. D. (2003). Improved Education in Musculoskeletal Conditions Is Necessary for All Doctors. Bulletin of the World Health Organization, 81, 677-683.

Almoallim, H., Bukhari, E., Amasaib, W., \& Zaini, R. (2012). How to Avoid Delay in SLE Diagnosis and Management. In H. Almoallim (Ed.), Systemic Lupus Erythematosus (pp. 219-242). Croatia: InTech.

http://dx.doi.org/10.5772/26498

Al-Nammari, S. S., James, B. K., \& Ramachandran, M. (2009). The Inadequacy of Musculoskeletal Knowledge after Foundation Training in the United Kingdom. The Bone and Joint Journal, 19, 1413-1418. http://dx.doi.org/10.1302/0301-620x.91b11.22445

Tian, Y., Jiu, W. H., Xu, F. F., \& Wang, X. D. (2011). Investigation and Analysis of Female Teachers' Burnout at Hainan Colleges and Universities. Northwest Medical Education, 19, 378-380.

Wang, X. J. (2010). Investigation and Analysis of the Burnout Status of College Female English Teachers. Journal of Jinan Vocational College, 1, 37-38, 41.

Xu, H. Y. (2010). A Study of University English Teachers' Professional Weariness. Education and Modernization, 3, 88-91. 